\title{
GAMBARAN KEJADIAN SKABIES DI PONDOK PESANTREN TRADISIONAL DAN PONDOK PESANTREN MODERN
}

Ella Elzatillah S, Siti Surasri*, Sri Mardoyo

Jurusan Kesehatan Lingkungan, Politeknik Kesehatan Kemenkes Surabaya

*Email korespondensi: sitisurasri@gmail.com

\begin{abstract}
ABSTRAK
Penyakit kulit scabies dapat ditularkan secara langsung melalui berjabat tangan, tidur bersama, dan melalui hubungan seksual, dan tidak langsung melalui bergantian pakaian, bergantian handuk, personal hygiene yang jelek dan sanitasi yang jelek, penyakit scabies juga dapat menular dengan cepat pada suatu komunitas, seperti dipondok pesantren. Dalam penelitian Mushallina Lathifa dinyatakan $76,7 \%$ santriwati pada PPM diniyyah pasia sebagai suspect scabies, dan berhubungan dengan faktor personal hygiene, kepdatan hunian.

Jenis penelitian deskriptif dengan pendekatan cross sectional bertujuan mengetahui gambaran faktor-faktor terjadinya penyakit scabies di PPT Gading Mangu Perak Jombang dan PPM Surabaya. Populasi penelitian adalah santri PPT Gading Mangu Perak Jombang dan PPM Surabaya, sampel sebesar 72 santri (PPT) dan 27 santri (PPM) diambil secara random.

Hasil penelitian di Pondok Pesantren Tradisional Gading Mangu Perak Jombang terdapat 52 santri $(72,2 \%)$ yang mengalami kejadian skabies, 19 santri $(26,3 \%)$ yang memiliki pengetahuan rendah, 40 santri $(55,5 \%)$ yang bergantian pakaian, 42 santri $(58,3$ $\%$ ) yang bergantian handuk, 50 orang $(69,4 \%)$ yang tidur berhimpitan, dan di Pondok Pesantren Modern Mahasiswa Surabaya terdapat 3 santri $(11,1 \%)$ yang mengalami kejadian skabies, 2 santri $(7,4 \%)$ yang memiliki pengetahuan rendah, 3 santri $(11,1 \%)$ yang bergantian pakaian, 1 santri $(3,7 \%)$ yang bergantian handuk, 0 orang $(0 \%)$ yang tidur berhimpitan. Tidak ada hubungan faktor dengan kejadian scabies.

Pondok Pesantren dan santri supaya meningkatkan perilaku hidup bersih dan sehat, terutama menjaga kebersihan lingkungan dan individu, tidak melakukan bergantian pakaian, tidak melakukan bergantian handuk, tidak melakukan tidur berhimpitan.
\end{abstract}

Kata kunci: Skabies, Pondok Pesantren, pengetahuan, perilaku.

\section{PENDAHULUAN}

Skabies adalah penyakit menular yang disebabkan oleh Sarcoptes Scabie varian hominis yang penularannya terjadi secara kontak langsung. Negara berkembang merupakan kelompok masyarakat yang paling banyak menderita penyakit Skabies. Prevalensi penyakit Skabies di Indonesia adalah 6$27 \%$ dari populasi umum dan cenderung lebih tinggi pada anak usia sekolah dan remaja. Di pondok pesantren prevalensi yang tinggi terdapat pada anak berusia 11-15 tahun. Berdasarkan Departemen Kesehatan Republik Indonesia, prevalensi penyakit skabies dalam masyarakat diseluruh Indonesia pada tahun 1996 adalah 4,6\% - 12,95\% dan skabies menduduki urutan ketiga dari 12 penyakit kulit tersering (Muzakir. 2008).
Penyakit kulit Skabies dapat ditularkan secara langsung misalnya berjabat tangan, tidur bersama, dan melalui hubungan seksual. Penularan secara tidak langsung misalnya bergantian pakaian, bergantian handuk, bergantian sprei, bergantian bantal dan bergantian selimut, dan banyak faktor yang membantu penilaian penyakit Skabies antara lain sosial ekonomi yang rendah, kepadatan penduduk, personal hygiene yang jelek, sanitasi yang jelek, dan hubungan seksual. Penyakit skabies juga dapat menular dengan cepat pada suatu komunitas, seperti di pondok pesantren. Pondok Pesantren juga merupakan salah satu tempat penularan penyakit skabies, jika sanitasi dalam pondok kurang baik. Penelitian yang dilakukan pada santriwati Pondok Pesantren Modern Diniyyah 
Pasia, Kecamatan Ampek Anggrek Kabupaten Agam, Sumatera Barat yang berjudul Faktor-Faktor yang Berpengaruh dengan Suspect Skabies menyatakan bahwa prevalensi suspect skabies sebesar $76,7 \%$ dengan diperoleh lima faktor yang berhubungan dengan suspect skabies yaitu personal hygiene $(p=0,006)$, kelembaban $(p=0,000)$, ventilasi $(p=0,000)$, kepadatan hunian $(p=0,014)$, dan dukungan pihak pesantren $\quad(p=0,000) \quad$ (Lathifa, Mushallina. 2014).

Pondok Pesantren merupakan tempat pendidikan dan pengajaran yang menekankan pada pelajaran agama Islam dan dilengkapi asrama sebagai tempat tinggal santri yang bersifat permanen. Pendataan pondok pesantren tahun 2011-2012 berhasil mendata 27.230 Pondok Pesantren yang tersebar di seluruh Indonesia (Rohmawati, Riris Nur.2010).

Dewasa ini di Indonesia sudah mulai banyak didirikan pondok pesantren yang memuat dan menampung berbagai lapisan tingkat pendidikan. Pondok Pesantren Gading Mangu Perak Jombang adalah salah satu pusat pendidikan agama Islam terbesar di Indonesia yang menekankan pada pengajaran Al Quran dan Al Hadits serta pembentukan akhlakul karimah generasi muda. Pondok Pesantren ini berada di desa Gading Mangu Perak, Jombang, Jawa Timur, berlokasi 400 meter masuk ke utara Pasar Jeruk, kecamatan Perak, kabupaten Jombang ( Ensiklopedia Islam).

Tidak hanya Pondok Pesantren Tradisional namun terdapat Pondok Pesantren tingkat mahasiwa. Di Surabaya, Pondok Pesantren Modern Mahasiswa Khoirul Huda atau lebih mudahnya dikenal PPM KH Surabaya merupakan salah satu pondok pesantren mahasiswa yang ada di Surabaya. Awalnya pondok ini adalah gria yang ditempati oleh para mahasiswa yang sedang menempuh studi/kuliah di Surabaya. Namun seiring dengan berjalannya waktu akhirnya pada tahun 2007 gria tersebut diubah statusnya menjadi pondok pesantren mahasiswa ( DPD LDII, 2017).
Data dari poskestren menunjukkan jumlah kasus penyakit skabies pada tahun 2016 di Pondok Pesantren Tradisional Gading Mangu Perak Jombang sejumlah 70 santri (dari 207 santri) 30\% dan di Pondok Pesantren Modern Mahasiswa Surabaya sejumlah 5 santri (dari 40 santri) 8\%.

Adanya perbedaan jumlah kasus skabies antara Pondok Pesantren Tradisional Gading Mangu Perak Jombang dengan Pondok Pesantren Modern Mahasiswa Surabaya,. Faktor lainnya adalah kepadatan santri di Pondok Pesantren Tradisional Gading Mngu Perak Jombang yaitu satu kamar $12 \mathrm{~m}^{2}$ ditempati 51 santriwati, tidur dengan beralaskan kasur yang tipis diatas lantai, dengan jarak berhimpitan, masih ditemukan sampah yang berserakan di tempat makan, tempat pengajian, kamar mandi, dan kurangnya kebersihan pondok. Sedangkan di Pondok Pesantren Modern Mahasiswa Surabaya adalah tiap kamar dihuni oleh 2 orang dengan 2 tempat tidur (100x200). Tujuan penelitian ini untuk mengetahui gambaran faktor faktor terjadinya penyakit Skabies di Pondok Pesantren Tradisional Gading Mangu Perak Jombang dan Pondok Pesantren Modern Mahasiswa Surabaya.

\section{METODE PENELITIAN}

Jenis penelitian ini adalah penelitian deskriptif dengan pendekatan cross sectional untuk mengetahui gambaran faktor faktor kejadian skabies di Pondok Pesantren Tradisional dan di Pondok Pesantren Modern (Studi di Kabupaten Jombang dan Kota Surabaya), Populasi dalam penelitian ini adalah seluruh santri di Pondok Pesantren Tradisional Gading Mangu Perak Jombang dan di Pondok Pesantren Modern Mahasiswa Surabaya. Berdasarkan data terakhir yaitu pada tahun 2017, jumlah santri di Pondok Pesantren Tradisional Gading Mangu Perak Jombang adalah 207 santri putri, dan jumlah santri di Pondok Pesantren Modern Mahasiswa Surabaya adalah 40 santri.Teknik pengambilan sampel untuk menentukan sampel yang akan digunakan dalam penelitian (Sugiyono, 2011). Sampel penelitian menggunakan teknik random sampling dengan cara 
diundi anggota populasi (lottery technique), Variabel yang diteliti adalah Kejadian Skabies, Tingkat pengetahuan responden, Perilaku santri putri bergantian pakaian, Perilaku santri putri bergantian handuk, Perilaku santri putri tidur berhimpitan

\section{HASIL DAN PEMBAHASAN}

Faktor Pengetahuan Tentang Skabies

Hasil uji X² Pengetahuan Terhadap Skabies di Pondok Pesantren Tradisional Gading Mangu Perak Jombang dapat dilihat pada Tabel 1 berikut ini :

Tabel 1

TABEL HASIL UJI $X^{2}$ PENGETAHUAN TERHADAP SKABIES DI PONDOK PESANTREN TRADISIONAL GADING MANGU PERAK JOMBANG TAHUN 2018

\begin{tabular}{|c|c|c|c|c|c|c|c|}
\hline \multirow{3}{*}{ Pengetahuan } & \multicolumn{4}{|c|}{ Suspect Skabies } & \multicolumn{2}{|c|}{ Total } & \multirow{3}{*}{$\begin{array}{l}\text { Uji } X^{2} \\
\text { p value }\end{array}$} \\
\hline & \multicolumn{2}{|c|}{$\mathrm{Ya}$} & \multicolumn{2}{|c|}{ Tidak } & \multirow{2}{*}{$\mathrm{N}$} & \multirow{2}{*}{$\%$} & \\
\hline & $\mathrm{N}$ & $\%$ & $\mathrm{~N}$ & $\%$ & & & \\
\hline Kurang & 10 & $52,6 \%$ & 9 & $47,3 \%$ & 19 & $100 \%$ & \\
\hline Baik & 41 & $77,3 \%$ & 12 & $22,6 \%$ & 53 & $100 \%$ & \\
\hline
\end{tabular}

Tabel 1 diketahui pada Pondok Pesantren Tradisional Gading Mangu Perak Jombang bahwa yang pengetahuannya kurang sebesar 26,3\%, sedangkan di Pondok Pesantren Modern yang pengetahuannya kurang sebesar 7,4\%. Selanjutnya hasi uji chi square pengetahuan dengan sakit scabies Pondok Pesantren Tradisional Gading Mangu Perak Jombang dan Pondok Pesantren Modern menunjukan $\mathrm{P}>0,05$ berdasarkan tabel dibawah ini, Maka Ho diterima, yang berarti tidak ada hubungan antara pengetahuan dengan terjadi skabies di Pondok Pesantren Tradisional Gading Mangu Perak Jombang

\section{Faktor Perilaku Bergantian Pakaian} Penghuni Pondok Pesantren Tradisional Gading Mangu Perak Jombang bahwa yang melakukan bergantian pakaian sebesar 55,5\%, sedangkan di Pondok Pesantren Modern yang melakukan bergantian pakaian sebesar $11,1 \%$. Selanjutnya hasi uji chi square pengetahuan dengan sakit scabies Pondok Pesantren Tradisional Gading Mangu Perak Jombang dan Pondok Pesantren Modern menunjukan $P>0,05$, Maka Ho diterima, yang berarti tidak ada hubungan antara bergantian pakaian dengan terjadi skabies di Pondok Pesantren Tradisional Gading Mangu Perak Jombang

Faktor Perilaku Bergantian Handuk Perilaku penghuni Pondok Pesantren Tradisional Gading Mangu Perak Jombang bahwa yang melakukan bergantian handuk sebesar 58,3\%, sedangkan di Pondok Pesantren Modern yang melakukan bergantian handuk sebesar $3,7 \%$. Selanjutnya hasi uji chi square pengetahuan dengan sakit scabies Pondok Pesantren Tradisional Gading Mangu Perak Jombang dan Pondok Pesantren Modern menunjukan $\mathrm{P}$ $>0,05$, Maka Ho diterima, yang berarti tidak ada hubungan antara bergantian handuk dengan terjadi skabies di Pondok Pesantren Tradisional Gading Mangu Perak Jombang.

Faktor Perilaku Tidur Berhimpitan Penghuni Pondok Pesantren Tradisional Gading Mangu Perak Jombang bahwa yang melakukan tidur berhimpitan sebesar 69,4\%, sedangkan di Pondok Pesantren Modern yang melakukan tidur berhimpitan $0 \%$. Selanjutnya hasi uji chi square pengetahuan dengan sakit 
scabies Pondok Pesantren Tradisional Gading Mangu Perak Jombang dan Pondok Pesantren Modern menunjukan $\mathrm{P}$ $>0,05$, Maka Ho diterima, yang berarti tidak ada hubungan antara tidur berhimpitan dengan terjadi skabies di Pondok Pesantren Tradisional Gading Mangu Perak Jombang.

\section{KESIMPULAN}

Kejadian Skabies di Pondok Pesantren Tradisional Gading Mangu Perak Jombang terdapat 52 orang penderita $(72,2 \%)$ dan Pondok Pesantren Modern Mahasiswa Surabaya terdapat 3 orang penderita $(11,1 \%)$, Tingkat pengetahuan responden di Pondok Pesantren Tradisional Gading Mangu Perak Jombang adalah baik 73,6\%dan Pondok Pesantren Modern Mahasiswa Surabaya adalah baik $92,5 \%$, Jumlah bergantian pakaian responden di Pondok Pesantren Tradisional Gading Mangu Perak Jombang adalah sebesar 55,5\% (40 orang) melakukan bergantian pakaian dan Pondok Pesantren Modern Mahasiswa Surabaya adalah sebesar 11,1 $\%$ (3 orang) melakukan bergantian pakaian,Jumlah bergantian handuk responden di Pondok Pesantren Tradisional Gading Mangu Perak Jombang adalah sebesar 58,3 \% (42 orang) melakukan bergantian handuk dan Pondok Pesantren Modern Mahasiswa Surabaya adalah sebesar 3,7 $\%$ (1 orang) melakukan bergantian handuk, Jumlah tidur berhimpitan responden di Pondok Pesantren Tradisional Gading Mangu Perak Jombang adalah sebesar 69,4\% (50 orang) melakukan tidur berhimpitan dan Pondok Pesantren Modern Mahasiswa Surabaya tidak melakukan tidur berhimpitan, Faktor pengetahuan, faktor bergantian pakaian, faktor bergantian handuk, faktor tidur berhimpitan tidak berpengaruh dengan kejadian scabies yang berada di pondok pesantren tradisional gading mangu perak jombang.

Bagi poskestren Perlu mengoptimalkan program pengendalian terjadinya penyakit skabies diantaranya melakukan pemeriksaan kesehatan kulit, melakukan tindakan pengobatan secara teratur pada anak yang terkena skabies dan melakukan pengarahan tentang menjaga kebersihan badan dan kebersihan lingkungan dan memberikan edukasi kepada santriwati di masing-masing pondok tersebut, dan mengatur tata ruang agar santri tidak tidur berhimpitan. Bagi santri Perlu mengoptimalkan upaya pencegahan kejadian skabies dengan menjaga barang pribadi untuk tetap bersih, mandi tiga kali sehari, jangan menumpuk baju-baju kotor, menjaga kebersihan kamarnya, dan menjaga kebersihan lingkungannya, dan tidak bergantian pakaian dan handuk. Bagi santri Perlu adanya penelitian lanjutan terkait faktor lain yang tidak diteliti dalam penelitian ini seperti personal hygiene, keadaan sosial ekonomi, kepadatan hunian.

\section{DAFTAR PUSTAKA}

Afraniza, Yuzzi. 2011. Hubungan Antara Praktik Kebersihan Diri dan Angka Kejadian Skabies di Pesantren Kyai Gading Kabupaten Demak. Skripsi. Universitas Diponogoro.

http://eprints.undip.ac.id/37475/1/Y uzzi.pdf diakses pada tanggal 8 Februari 2017.

Ali, Khaidar. 2016. Karakteristik Individu, Personal Hygiene, Perilaku Sehat dan Kejadian Skabies pada Santri (Studi di Ponpres Khalafi dan Salafiyah Kecamatan Mayang Kabupaten Jember). Skripsi. Universitas Jember. http://repository.unej.ac.id/bitstrea $\mathrm{m} /$ handle/123456789/77988/Khaida r\%20Ali\%20$\% 20122110101051$.pdf?sequence $=1$ tanggal 28 Agustus 2017.

Azizah, Umi. 2011. Hubungan Antara Pengetahuan Santri tentang PHBS dan Peran Ustadz dalam Mencegah Penyakit Skabies dengan Perilaku Pencegahan Penyakit Skabies (Studi pada santri di Pondok Pesantren Al-Falah Kecamatan Silo Kabupaten Jember). Skripsi. UniversitasJember.

http://repository.unej.ac.id/bitstrea m/handle/123456789/ 
5588/Skripsi.pdfce $\backslash=1$ diakses pada tanggal 8 Februari 2017.

DPD LDII, 2017. Pondok Pesantren Mahasiswa Khoirul Huda Surabaya. http:///diisurabaya.org/pondokpesantren-mahasiswa-khoirul-hudasurabaya/

Ensiklopedia Islam. Pondok Pesantren Gading Mangu Perak Jombang. http://id.islam.wikia.com/wiki/Pond ok Pesantren Gading Mangu Pera k Jombang

Fernawan, niky surya. 2008, perbedaan Angka Kejadian Skabies di Kamar padat dan Kamar tidak Padat di Pondok Pesantren Modern Islam PPMI Assalam Surakarta. Skripsi. UMS. Tidak di Publikasikan. http://etd.eprints.ums.ac.id/4352/1/ J500040010.pdf diakses pada tanggal 8 Februari 2017.

Frenki,2011, Hubungan Personal Hygiene Santri dengan kejadian Penyakit Kulit Infeksi Skabies dan Tinjauan Sanitasi Lingkungan Pesantren Darel Hikmah Kota Pekanbaru Tahun 2011. Skripsi. Universitas Sumatera Utara.

http://etd.eprints.ums.ac.id/123456 789/30896/4/Chapter \% 2011.pdf diakses pada tanggal 18 februari 2017

Lathifa, Mushallina. 2014. Faktor-Faktor yang Berpengaruh dengan Suspect Skabies pada Santriwati Pondok Pesantren Modern Diniyyah Pasia, Kecamatan Ampek Anggrek Kabupaten Agam, Sumatera Barat. http://repository.uinjkt.ac.id/dspace bitstream/123456789/25606/1/Mus hallina\%20Lathifa\%20-\%20fkik.pdf tanggal 28 Agustus 2017.

Muzakir. 2008. Faktor yang Berhubungan Dengan Kejadian Penyakit Skabies pada Pesantren di Kabupaten Aceh Besar Tahun 2008. Skripsi. Universitas Sumatra Utara. http://repository.usu.ac.id/bitstream 123456789/

6797/1/047023015.pdf diakses pada tanggal 8 februari 2017.

Noor, Nur Nasry. 2008. Epidemiologi. Jakarta : Rineka Cipta.

Nugraheni, Dwi Nurlaili. 2008, Pengaruh Sikap Tentang Kebersihan Diri
Terhadap Timbulnya Skabies ( gudik ) pada Santriwati dipondok Pesantren Al- Muayyad Tahun 2008. Skripsi. Universitas Muhammadiyah Surakarta. http://eprints.ums.ac.id/889/1/J210 040035.pdf diakses pada tanggal 29 februari 2017

Purba, Christine Vita Gloria. 2013. Pengaruh Personal Hygiene dan Sanitasi Lingkungan Terhadap Kejadian Skabies pada Anak Usia Sekolah di Kecamatan Lubuk Pakam Kabupaten Deli Serdang Tahun 2013. Tesis. Universitas Sumatra Utara.

http://repository.usu.ac.id/bitstream $\angle 123456789 /$

43960/4/Chapter\%2011.pdf diakses pada tanggal 8 februari 2017.

Rohmawati, Riris Nur. 2010. Hubungan Antara Faktor Pengetahuan dan Perilaku dengan Kejadian Skabies di Pondok Pesantren Al-Muayyad Surakarta. Skripsi. Universitas Muhammadiyah Surakarta. https://saidnazulfiqar.files. wordpress.com/2011/10/skripsihubungan-antara-faktorpengetahuan -dan-perilaku.pdf. Diakses pada tanggal 18 februari 2017

Ratnasari, Amija Fadila dan Saleha Sungkar. 2014. Prevalensi Skabies dan faktor - faktor yang Berhubungan di Pesantren $X$, jakarta timur. Skripsi. Universitas Indonesia. http://journal.ui.ac.id/index.php/eJK I/article/view

File/3177/2470. Vol. 2, No.1 diakses pada tanggal 8 februari 2017. 